\title{
Prediction of Facilities and Infrastructure Needs Digital Architecture Technology in the Era of Industry Revolution 4.0 and Readiness of Vocational High School Program
}

\author{
Qatrunnada Ryan Syifa, Mokh. Syaom Barliana, Fauzi Rahmanullah* \\ Dept. of Architectural Engineering Education \\ Faculty of Technological and Vocational Education \\ Universitas Pendidikan Indonesia \\ Bandung, Indonesia \\ rqatrunnada@student.upi.edu, aombarli@upi.edu,*fauzirahmanullah@upi.edu
}

\begin{abstract}
Digital technology which is a characteristic of industrial revolution 4.0, affects the change in drafter competence which is the output of graduates from the vocational high school program. These changes need to be accompanied by adequate quality infrastructure. This study aims to predict the need for drafters/technician facilities and infrastructure when viewed from existing technological developments. The list of the need for facilities and infrastructure will be an indicator to assess the vocational high school program's readiness in Bogor. The readiness level is limited to the state of the learning room, software, and hardware that supports learning in the era of the industrial revolution 4.0. This study used a quantitative descriptive method with a sample of vocational high school 2 Bogor. From the results of this study, the types of software and hardware needed by the drafter/technician are; (1) AutoCAD; (2) ArchiCAD; (3) SketchUp; (4) Complex software such as Revit, Contructware, and Ecotect; (5) Photoshop; (6) 3ds Max; (7) Civil 3D; (8) Corel Draw; and (9) 2D and 3D printers. For an overview of future classroom conditions, they were adapting the concept of smart classrooms. Regarding the readiness of the vocational high school program, it is very ready.
\end{abstract}

Keywords—predictions, facilities, and infrastructure, vocational readiness, digital architectural technology

\section{INTRODUCTION}

Along with the development of science, technological advances are also developing rapidly, marked by the discovery of assistive devices that replace humans and animals' work. Changes that occur suddenly and fundamentally can interpreted as a revolution [1]. Meanwhile, according to human civilization's history, the industry is defined as humans' work with their expertise and skills, as in conventional humans who use animals as tools to facilitate their work. Along with the times, the work of human hands was supported by assistive devices that replaced humans' and animals' roles. From this understanding, it can be interpreted that the industrial revolution is a change in all aspects of the industry related to the human development of work equipment.

The industrial revolution classifies into several stages [1] The first stage (1760-1840) is marked by the invention of steam engines and water-powered machines that help human work in manufacturing, mining, transportation, and technology. Then, at the end of the 19th century and the beginning of the 20th century, the widespread use of electricity increased society's productivity, which marked the second industrial revolution. Then the use of computer technology for manufacturing automation in the 1960s marked the third revolution.

In the early $21^{\text {st }}$ century, the world is already at the fourth stage in the Industrial Revolution, which was officially born in Germany to be precise when the Hannover Fair was held in 2011. Meanwhile, Indonesia itself began implementing industry 4.0 on 30 April-4 May 2018 when the minister of industry held working visits to Czech and Germany which then compiled the Making Indonesia 4.0 program.

Industry 4.0 is a paradigm shift in the industrial sector towards digitalization. Digital is familiar because it is often used in various aspects of life, from health, economics, transportation, education, and architecture. The first phase of digital technology in the design world only acts as a tool that helps architects produce more quickly and accurately drawing products. However, digital technology can be used as a thinking tool at this stage, such as solving problems in the architectural design process [2].

With these various advantages, architects have been influenced and experienced progressive development to innovate intricate architectural designs in form, structure, function, material, and environment. For example, in the Dubai Opera House's design process by Zaha Hadid, computer assistance helps visualize the design. By using the help of 
computers, the work will be more concise and save much time [3].

However, other impacts are detrimental to the architectural profession (and its team) behind these advantages. Primasetra, in the draft minutes presented at the 2018 Aptari Meeting, stated that with the trimming of architects' work process, especially for high complexity buildings, the consequence is the loss of the role of junior architects and drafter [4]. All that was left was the leading architect with his computer.

This phenomenon is certainly a challenge and an opportunity for the world of education facing the wave of the Industrial Revolution 4.0 to create competitive human resources. From the results of observations made during the apprenticeship to become a teacher, senior secondary school building program vocational to date the output approach of its graduates as a drafter. As previously explained, the drafter profession will impact the wave of the Industrial Revolution 4.0. The vocational high school program's readiness in facing the 4.0 industrial revolution must be known so that vocational education in Indonesia can run relevant to the Making Indonesia 4.0 roadmap, which focuses on improving the quality of human resources.

Also, to catch up with Indonesia's delay in technological development in the era of the industrial revolution 4.0, research is needed that discusses the prediction of the need for drafter/technician facilities and infrastructure to work optimally. The facilities and infrastructure in question are not limited to the space conditions, but also the need for hardware and software types to support the needs of digital architecture.

\section{METHODS}

The method used in this research is quantitative descriptive method with research instruments in the form of a questionnaire and literature study. Collecting data and facts regarding the drafter/technician's needs was carried out through literature study. From various sources, data can be obtained regarding the infrastructure needs of architects and vocational high school students' needs in the era of the industrial revolution 4.0. From these two data, it can be obtained a list of temporary infrastructure and facilities requirements for drafter / technicians in the era of the industrial revolution 4.0. The list that has been obtained is then used as an instrument to compile the first questionnaire that will be circulated to architects, consultants, and digital architecture lecturers for validation.

Furthermore, data from the first instrument is analyzed and used as a second questionnaire instrument to ask about its availability in schools which will then become an indicator of the level of readiness of vocational high schools in facing the era of the industrial revolution 4.0
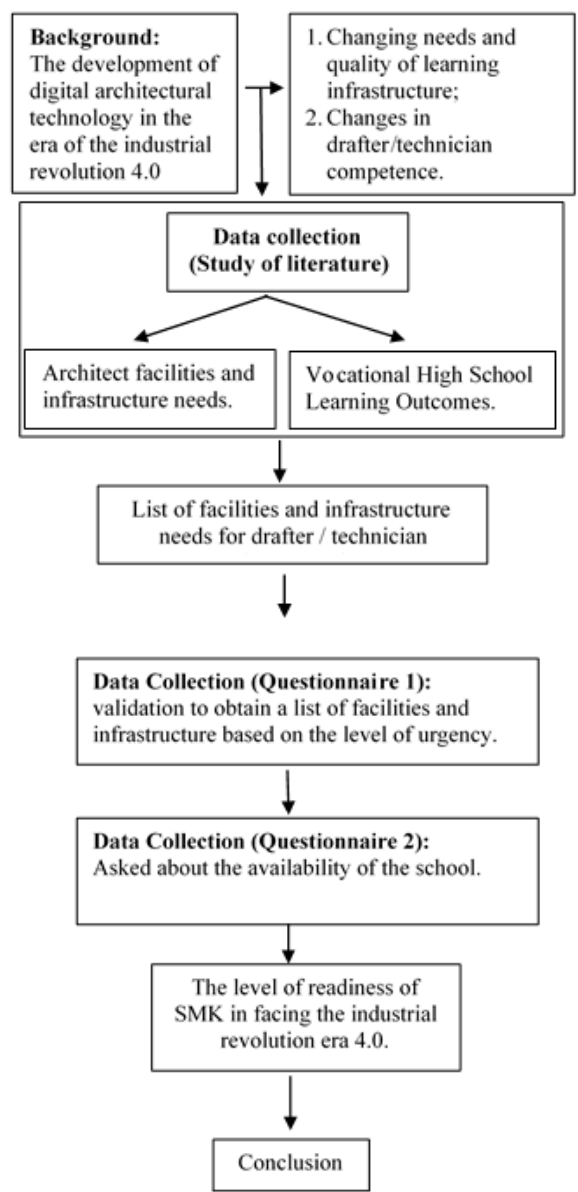

Fig. 1. Research flowchart.

\section{RESULTS AND DISCUSSION}

The development of technology in the world of architecture has developed rapidly, wherein the early stages, the influence of digital technology was only as a drawing aid, but at the next stage, digital technology was able to help architects find new concepts in designing. Several software and hardware types are used, such as Autodesk Revit, AutoCAD, Ecotect, Green Building Studio Robot, QTO, Contructware, ArchiCAD, MEP Modeler, to the most accessible software such as SketchUp. With various technological supports that can make it easier for architects, the discourse to accelerate production in design is becoming increasingly real.

The continuous development of technology has changed the needs and quality of learning infrastructure and drafter/technicians' competence. Vocational High Schools (SMK) as a vehicle for producing human resources must produce graduates who are trained and able to compete in domestic and foreign labor market markets. Therefore, the competence of future drafter/technician candidates has different competency demands such as; (1) able to adapt; (2) can develop themselves; (3) creative and innovative; (4) nationalism, (5) enthusiasm and curiosity; and (5) knowledge of digital literacy. 
Meanwhile, the quality of learning infrastructure needs to be improved, for example, in classrooms' design.

From the research results, it can be known that the types of facilities and infrastructure needed by drafter/technicians as the output of vocational high school program graduates are following the era of the industrial revolution 4.0. The types of facilities and infrastructure referred to are limited to 3 (three) aspects: software, hardware, and room conditions.

A. Software

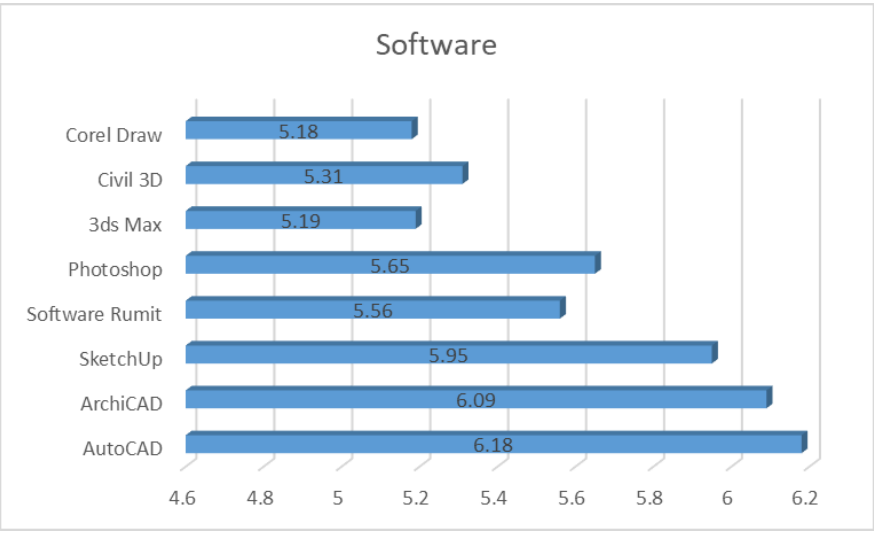

Fig. 2. Types of software required by drafter/technician.

Figure 2 shows the type of software a prospective drafter/technician needs to master based on the level of urgency. The higher the score, the higher the relationship between using the software in the world of work. From this data, the order of software that a prospective drafter/technician needs to master is as follows; (1) AutoCAD; (2) ArchiCAD; (3) SketchUp; (4) Complex software such as Revit, Contructware, and Ecotect; (5) Photoshop; (6) 3ds Max; (7) Civil 3D; and (8) Corel Draw.

\section{B. Hardware}

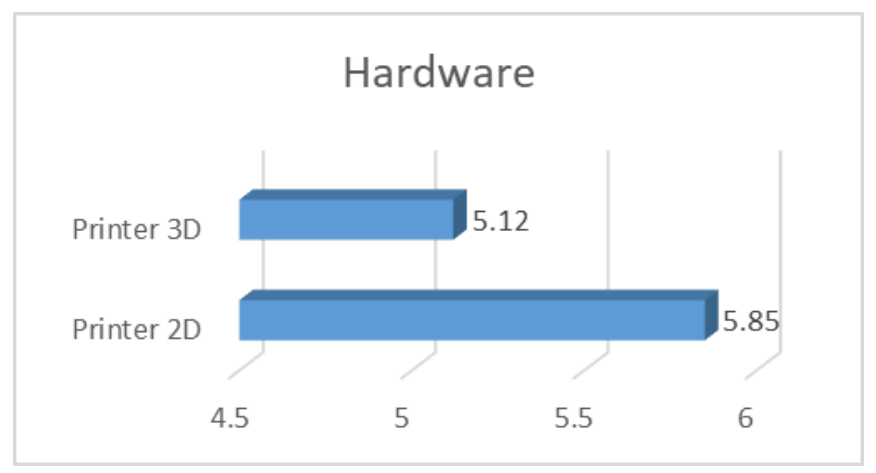

Fig. 3. Types of hardware required by drafter/technician.

Figure 3 shows the type of hardware that a prospective drafter/technician needs to master. Prospective drafter/technicians' ability to operate 2D printing machines is still more necessary than operating $3 \mathrm{D}$ printing machines.

\section{Classroom Conditions}

The smart classroom design implemented in many excellent schools is considered useful in adapting to the era of the industrial revolution 4.0. Therefore, this concept may also be applied in the vocational high school program in the future. To apply this concept, there are several aspects that need to be fulfilled which can be seen in the following graph:

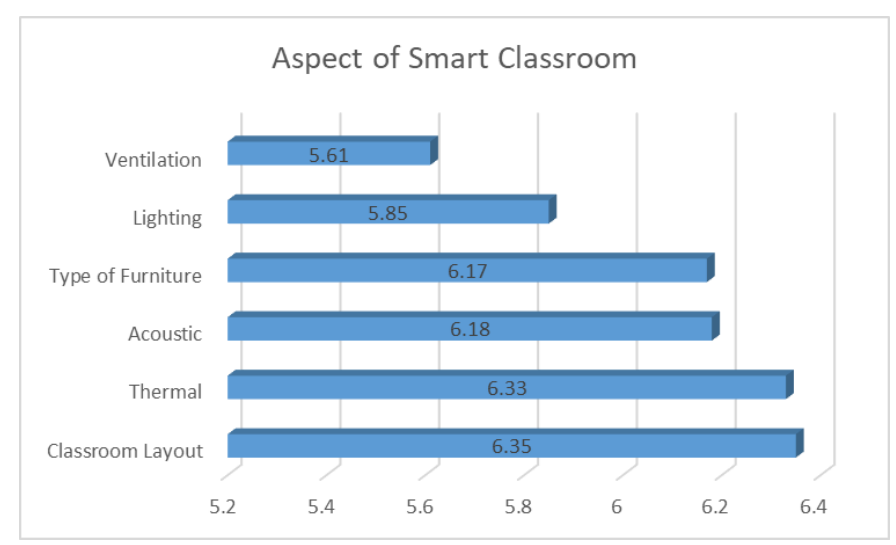

Fig. 4. Classroom conditions required by drafter/technician.

Figure 4 shows what aspects must be met and the level of these aspects' tendency to influence student productivity. In addition to the classroom design, the main characteristic of applying the smart classroom concept is the use of innovative types of furniture that have adapted to the latest technological developments so that they can meet the diverse needs of teachers and students with a high level of mobilization.

After knowing the types of facilities and infrastructure needed by drafter/technician candidates, the next step is to find out the level of readiness of the vocational high school program in fulfilling the infrastructure. The school that was the sample in this study was vocational high school 2 Bogor. Based on the research results, it can be seen that the level of readiness of vocational high school 2 Bogor in facing the era of the industrial revolution 4.0 is in the very ready category which is relevant to national data in 2019 which states that $50 \%$ of vocational high school respondents throughout Indonesia say they are ready to face uncertainty in 21 st century which includes policy turbulence, technology turbulence, market turbulence, and competitiveness turbulence.

\section{CONCLUSION}

The facilities and infrastructure needed by prospective drafter / technicians are limited to 3 (three) aspects: software, hardware, and room conditions. In the software aspect, the types of equipment needed are; (1) AutoCAD; (2) ArchiCAD; (3) SketchUp; (4) Complex software such as Revit, Contructware, and Ecotect; (5) Photoshop; (6) 3ds Max; (7) Civil 3D; and (8) Corel Draw. Meanwhile, for the hardware aspect, the types of equipment needed are 2D printers and 3D printers. Both of these aspects, both software and hardware, need to be provided by schools to students so that the quality of the graduates produced can compete with the job market. 
In the third aspect, namely room conditions, the smart classroom concept is considered relevant to students' needs in the era of the industrial revolution 4.0. This concept's distinctive feature is the use of innovative types of furniture with the latest technology that is more flexible and able to support teachers' and students' diverse needs and a high level of mobilization. Factors that are considered in implementing the smart classroom concept include; (1) room layout; (2) thermal; (3) acoustics; (4) types of furniture that have innovated; (5) lighting; and (6) ventilation.

Overall vocational high school 2 Bogor in facing the era of the industrial revolution 4.0 feels very ready. However, this research still lacks time and space so that the data obtained is still in the form of acknowledgment from respondents and confirmed from pre-existing theories. Further research related to this theme needs to be carried out to obtain deeper information.

\section{ACKNOWLEDGMENT}

Q.S.F. would like to thank all those who have played a role in this research, especially to respondents consisting of architects, consultants, digital architecture lecturers, and the vocational high school 2 Bogor, so that this research can be written and informed to students, schools, and stakeholders.

\section{REFERENCES}

[1] K. Schwab, "The fourth industrial revolution," (-): Crown Buisiness, 2016.

[2] RA Putra, "The role of digital technology in the development of the world of architectural design (Peran teknologi digital dalam perkembangan dunia perancangan arsitektur),". vol. 4 (1), pp. 67-77, 2018.

[3] R. Kasali, "The great shifting," Jakarta: Gramedia Pustaka Utama, 2018.

[4] A. Primasetra, Peranan prodi arsitektur, dalam menghadapi Era Revolusi Industri 4.0. 2018 